\title{
The Use of Tablets Distributed within the Scope of FATIH Project for Education in Turkey (Is FATIH Project a Fiasco or a Technological Revolution?)
}

\author{
Tugce Gamze Isci, Selcuk Besir Demir*
}

Department of Primary Education, Faculty of Education, Cumhuriyet University, Turkey

Copyright (C) 2015 by authors, all rights reserved. Authors agree that this article remains permanently open access under the terms of the Creative Commons Attribution License 4.0 International License

\begin{abstract}
This study aims to profoundly investigate the usage of tablets distributed within the scope of FATIH Project in Turkey in terms of teacher views. The study was conducted with case study design, which is one of the qualitative study methods. The participants in the study were determined using critical case sampling. Data was collected using semi-structured interviews made with 6 branch teachers working in nickname high school in Sivas during the spring semester of 2014-2015 educational year. As a result of analysis of the interview data, two main themes were determined: the current usage and aims for using the tablets distributed by the Ministry of Education within the scope of FATIH Project and technical problems related to tablets and solution suggestions. According to the findings, it was concluded that the teachers did not use the tablets in the classroom for reasons such as technical problems and not having sufficient in-service education and the tablets have become play things for the students.
\end{abstract}

Keywords FATIH Project, Tablet Computers, Computer-assisted Teaching, Information Technologies

\section{Introduction}

Information and communication technologies became an indispensable part of our lives as they have spread in every area of life. These technologies were integrated with many areas because of the convenience they provided for the daily life [28, 34, 44, 45, 49]. Efforts to integrate information and communication technologies with education sped up throughout the world with ever increasing use information and communication technologies, realization of the benefits of these technologies, the increase in the number of individuals using the technology and the decrease in the ages of people using these technologies [1,4]. Adapting technological developments to education ensured positive changes both for teachers and students during educational process [35, 47]. Today, many countries increase level of technology use in their educational systems since technology plays an important role in the quality of education [46].

In Turkey, various institutions and organizations conduct several studies and organize several events to keep up with the developments regarding technology, to conduct research and develop plans about it in relation to many areas from education to health and from agriculture to industry [1]. Within this context, projects especially regarding the use of information and technology in education have been developed in Turkey $[19,21]$. Within this scope, a project known as the Movement of Enhancing Opportunities and Improving Technology (FATIH) implemented with the cooperation between the Ministry of Education and the Ministry of Transportation was announced in November 2010 in order to improve the success rate of the students and ensure the efficient use of technology within classrooms [2, 32]. The aim of the FATIH Project was to provide LCD Panel Interactive Whiteboard and internet network infrastructure for 620,000 classrooms in the schools throughout Turkey at the same time providing a tablet to every teacher and student [7, 25]. Authorities started to distribute gradually to students within the scope of the project.

When the studies in the literature regarding the use of tablet computers in educational process were investigated, it was stated [12] that tablet computers could be used by the students to acquire information. In the studies conducted by Bonds, Raacke \& Raacke [10], Çetinkaya and Keser, [17], Tekerek, Altan and Gündüz, [48], it was determined that students had positive attitudes regarding the use of tablets. Tablet computers rendered lessons more entertaining and increased the motivation of the students [20]. Also, tablet computers create an environment in which learning opportunities are maximized. Galligan\&ect.[26], Bush \&Cameron [11], on the other hand, stated in their study that tablet computers should be used as technological materials 
since they contributed to the academic success of the students. Also Crichton, Pegler\& White, [15]; Dündar and Akçayır, [20] stated that iPads and tablets played an important role in improving the success rate of students and efficiency in education.

In addition to the above-mentioned positive aspects of using tablets, it is seen that various problems were also encountered while using tablets. IP addresses' mixing up, impossibility of playing videos, inability to transfer data and batteries' dying quickly are among the technical problems that were countered [38]. Johnson, [30] stated in his study that students could not have practices since they could not use tablets outside school and this restricted information transfer to students outside school. Teachers, on the other hand, stated that the tablets did not have programs such as Word and PowerPoint, they are limited in terms of doing homework, the students did not listen to the lectures since they are engaged with tablets, they could not control students' tablets and students did not ask enough questions [6, $17,38,44]$.

According to Kaymak and Yilmaz [37], students and parents should be informed about using technology and the details regarding the studies made about the results of the technology used should be explained. Due to rapidly developing technology, hardware and software should be continuously followed and the tablets that were distributed should be continuously updated, teachers should be provided in-service training and students should be informed about using the tablets and the problem related to computers $[8,18$, 19, 24, 33].

Based on the above-mentioned theoretical framework, the effect of tablets distributed in Turkey on the academic success rate, attitudes of teachers and students regarding tablet computers and the problems encountered while using tablet computers were investigated in depth in the literature. However, no studies about students' purpose of using tablets were encountered.

Considering the objectives expected to be achieved with FATIH Project, it is important for the efficiency of the project that the students use the tablet computers for their intended use. Within this context, the study aims to investigate in depth for which purposes the tablet computers distributed within the scope of FATIH Project are used according to teachers' opinions.

Turkish Republic has spent millions of dollars on the FATIH project and the project has been defined as a technological revolution for Turkish national education. In this context, when the cost and the aims of the project are considered, it becomes more of an issue to evaluate the use and effectiveness of tablets, which constitute is one of the several dimensions of the project. In this way, the study will provide projections for decision makers.

\section{Method}

\subsection{Study Design}

This study aims to investigate in depth for which purposes the tablet computers distributed within the scope of FATIH Project implemented with the cooperation between the Ministry of Education and the Ministry of Transportation are used according to teachers' opinions. Within this context, the study was conducted with the case study method which is one of the qualitative study methods. A case study is the type of study that focuses on detailed explanations regarding one or more cases [31].

Case study is an approach in which researchers collect detailed and in-depth information regarding a case in real life, a current issue or a case in a certain period [13]. According to Patton [43], on the other hand, it includes the organization of the data according to special cases to investigate in depth and compare. The study was conducted according to the case study design since it aimed to profoundly investigate the usage of tablets distributed within the scope of FATIH Project according to teachers' opinions.

With FATIH project conducted in Turkey, it was aimed to equip every classroom in the country with smart board and internet access and tablet computers were distributed to every teacher and student. In the scope of the project, tablets are still being distributed and smart boards are being installed. The scope of this study is restricted with the use of tablet computers, which is only one part of the FATIH project.

\subsection{Study Group (Participants)}

Critical case sampling, which is one of the purposeful sampling types in qualitative studies, was used in the study. Critical case sampling is the sampling methods chosen to know a subject verified previously better or to study in depth the cases known to be especially important [31]. Critical cases mean the cases underlining something important very clearly or the cases which are especially important under normal conditions [43]. Within this context, critical case sampling was used since it aims to profoundly investigate the tablets distributed within the scope of FATIH Project in terms of teachers' opinions.

Teachers working in nickname high school in the city center of Sivas were chosen as the study group. The study was limited with 6 branch teachers (3 History teacher and 3 Geography teachers).

Table 1. Information Regarding Participants

\begin{tabular}{|c|c|c|c|c|}
\hline Participants & Gender & Branch & $\begin{array}{c}\text { Working } \\
\text { Time }\end{array}$ & $\begin{array}{c}\text { In-service Training } \\
\text { (FATIH Project) }\end{array}$ \\
\hline K1 & Male & History & 8 Years & Yes \\
\hline K2 & Male & Geography & 16 Years & Yes \\
\hline K3 & Male & History & 22 Years & Yes \\
\hline K4 & Female & Geography & 20 Years & Yes \\
\hline K5 & Male & History & 10 Years & No \\
\hline K6 & Female & Geography & 30 Years & Yes \\
\hline
\end{tabular}


All of the teachers are college graduates and have not received any training for using tablet computers during their undergraduate education. However, like all teachers working for the Turkish Ministry of Education, the participants received in-service training about using tablets as a part of FATIH project.

\subsection{Data Collection Tools and Process}

Interviewing, which is one of the data collection tools for qualitative studies, was used in the study. Interviewing aims to reach people's points of views [43]. Within this context, the usage of the tablets distributed within the scope of FATIH Project was tried to be determined by means of the semi-structured interviews. New questions were asked in the semi-structured interview forms in order to get deeper compared to the answers given by the participants during interviews and to get more detailed data. Additional questions were asked according to the answers given by the participants to the interview questions. Studies in the literature Ayvacı, Bakırcı and Başak, [6]; Çetinkaya and Keser, [17]; Kamac1 and Durukan, [32]; Kurt et al., [38]; Pamuk et al., [44] were compared in line with the purpose of the study and interview form questions were prepared. Prepared draft interview questions were examined by an expert lecturer. Interview questions were organized according to the expert opinion and the purpose of the study. Interview questions were rephrased in the next stage in terms of language and narration, possible incoherency and understanding difficulties.

A pilot study was made with 2 branch teachers, who are not participants, in order to determine the quality and sufficiency of the questions in the interview form. Questions, which teachers had difficulties in understanding, were rearranged after the pilot application.

Using the information obtained from the applications that were made, the interview form was given its final shape and addressed to participants as a part of the study. All questions in the interview form were asked to the participants. Additional questions were also addressed to the participants to investigate the subject in depth according to the answers that were given.

Within the scope of the study, interview questions were asked in a silent environment, which will not affect the study. The study was carried out in January and February 2015. 135-minutes long interviews were made within the scope of the study. The purpose of the study was explained, confidentiality of the data was guaranteed and detailed information about the interview questions and the purpose of the study was given to them so that they could act more comfortably and sincerely during face to face interviews.

\section{Data Analysis}

\subsection{Interview Transcriptions}

All interviews made with the participants during the study period were recorded using a recording device. Sound records were transcribed and converted into written texts in the Microsoft Word program. These texts were presented to the participants one by one and they were asked to approve that these were their own opinions.

\subsection{Data Coding}

Transcription of the interview data was carefully read by two researchers before the data was coded. In addition to that, dimensions important within the framework of the study's purpose were determined and the meaning of each dimension was tried to be determined. Concept, for which participants stated their opinions, was used as codes during the coding process as much as possible. However, in the cases when the words and concepts used by the participants were insufficient during the coding process, other concepts to express the thought/situation the best were determined as codes by the researchers. Line by line analysis approach stated by Patton [43] was used while coding the data. One word, phrases or a sentences formed units for data analysis.

\subsection{Interpretation Techniques}

Inductive descriptive analysis, content analysis and constant comparison technique among the qualitative data analysis techniques were used during the interpretation process of the interview data $[40,41]$.

Descriptive analysis was used in analyzing the data obtained during the interviews. Direct citations from the teachers' opinions were given in order to reflect the opinions of the interviewed individuals in the descriptive analysis. Content analysis was used in order to obtain concepts and relations that can explain the data [51]. On the other hand, data was firstly divided into parts and these parts were investigated and compared in the content analysis. After that, meaningful concepts were formed from these parts and the codes reminding the same concepts were combined under the same category. Cohesion was achieved from the themes obtained from the data and interpreted in the last stage. The pattern obtained as a result of the interview transcriptions is presented in Figure 1. 


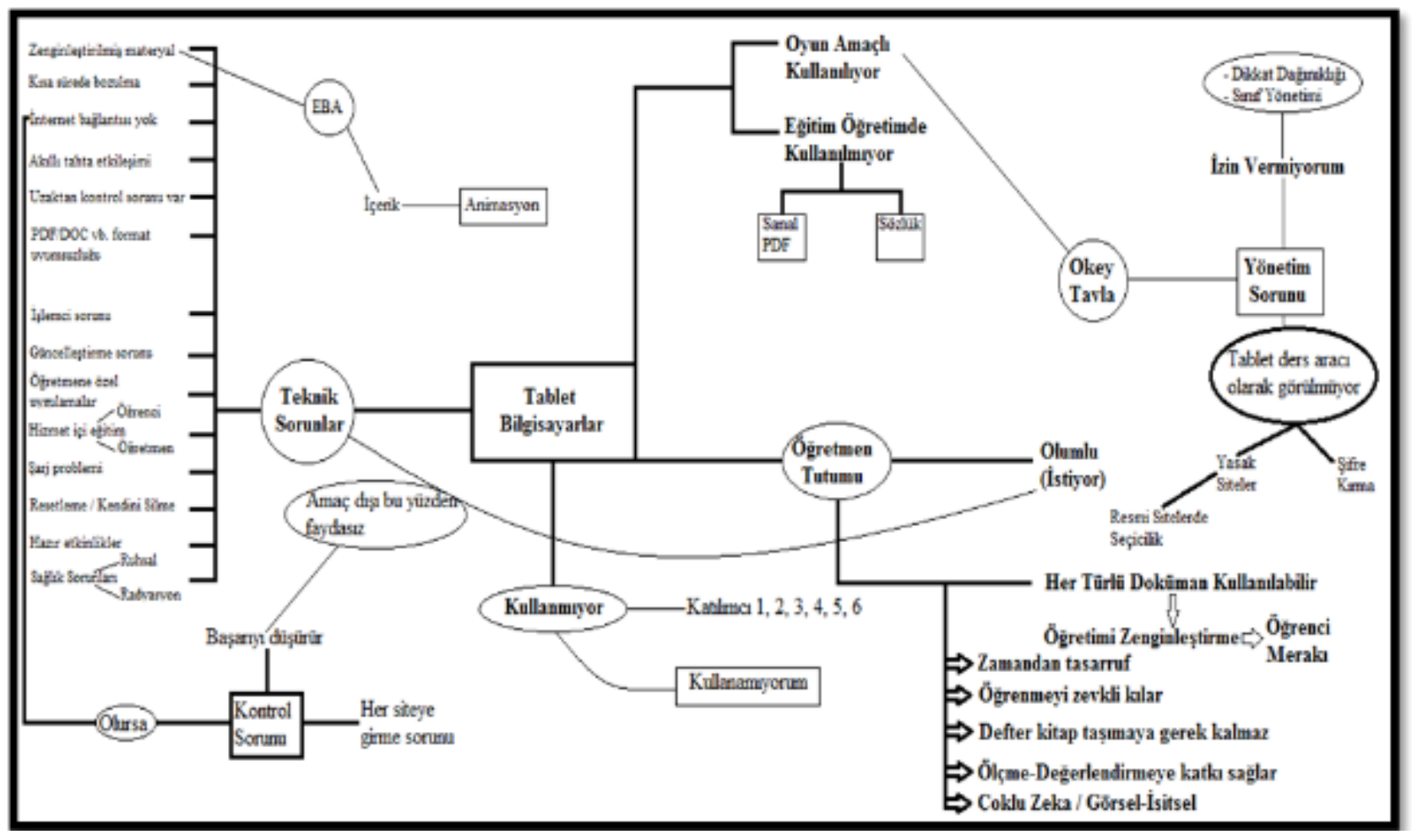

Figure 1. Figure Obtained as a Result of the Analysis

\subsection{Credibility, Transmissibility, Consistency and Confirmability in the Study}

\subsubsection{Credibility}

The relevant literature was examined in order to improve the credibility (internal validity) of the study after the interview form was developed and it was based on a conceptual basis related to the subject. By providing them with necessary time during the data collection process, it was ensured for the participants to behave sincerely. Opinions of the participants were written down after the interview and they were asked to confirm whether or not the texts were their own opinions.

On the other hand, during the content analysis stage of the study, attention was paid to render the themes that were obtained to be wide enough to include the relevant concepts but narrow enough to exclude the concepts irrelevant to the subject outside the scope of the study. Integrity was tried to be achieved between the concepts in the study and the obtained findings. Attention was paid to behave objectively in all the stages of the study

\subsubsection{Transmissibility}

Steps taken in the stages of the research process to improve the transmissibility of the study were presented with details to the reader and attention was paid to give detailed descriptions. It is aimed to visualize the research process in the minds of readers using the detailed descriptions within the scope of the study. For this reason, details were directly presented in findings and comments section. It is considered that the descriptive data collected within this scope can be transferred to similar study groups. It is necessary for the results obtained in this study to be understood in the same or similar way by all the readers of the study. Within this context, transfers regarding the study were summarized in a simple and understandable way in order to visualize the research process and research environment in the minds of the readers.

\subsubsection{Consistency}

All findings obtained in the study were directly presented to the readers without making any comments or generalizations in order to improve the consistency (internal reliability) of the study. Data obtained within the scope of the study were evaluated and coded separately by an academician other than the researcher, who had a grasp of qualitative studies, and a consensus was reached between the versions of coding. Consistency of the codes created independently by the two researchers was determined by marking the codes as "Consensus" or "Divergence". Reliability formula suggested by Miles \&Huberman (1994) $[$ Reliability $=$ Consensus $/($ Consensus + Divergence $)]$ was used to calculated the reliability of all these codes. A result between $88 \%$ and $93 \%$ was obtained in reliability calculations made for every problem.

\subsubsection{Confirmability}

The researchers allowed relevant people to examine raw data and coding obtained during the process with the aim of ensuring confirmability of the study (external reliability). 


\section{Findings}

As a result of analyzing the interview data:

1) Current use and intended uses of the tablet computers distributed by the Ministry of Education within the scope of FATIH Project

2) Two subcategories were obtained as technical problems and the relevant solution suggestions. These categories are related to each other and affect each other directly:

\section{1) Usage and Intended Uses of Tablet Computers}

All participants stated that they did not use tablet computers and they had students turn them off when students used tablets in the classroom. It was determined that they associated the situation more with the technical problems specified in the second theme when they were asked "Why do not you use the tablets?". When asked about the intended uses of the tablet computers, they stated that the table computers were used only for games by the students, students played games with those tablets in canteens, cafeterias, classrooms, in and outside the school and they even installed strategy games, racing games, rummikub and backgammon games on these computers. When Participant 4 was asked "For which purposes students use the distributed tablet computers?" He answered, "Of course for playing games. They have games installed on the tablets in their hands. They are talking to each about games. They are asking each other how to install games." When Participant 5 was asked the same question he answered "I saw them using the tablets even as trays." Participants 6 answered the same question with the statement "I never saw a student use a tablet computer for education. Children do not even know what to do with these tablets". When they were asked the question "Are the tablet computers used only for playing games and are not they used in educational process at all?", the participants stated that they could use the tablets only as the PDF versions of dictionaries and textbooks and they do not currently use these tablets for any other purpose.

It was understood that all the teachers had positive attitude towards tablets and FATIH project. Teachers stated that they wanted to use the tablets that were distributed, and that using tablets could enrich education process and appeal to the curiosity of the students, make learning enjoyable, prevent problems such as carrying books and notebooks, activities regarding tests, journals and assessment and evaluation could be done using tablets, tablets could address multiple intelligence with visual and written materials thus enriching the teaching process and saving time. When asked the question "Do you believe using tablets in teaching this subject will increase the success rate of the students?" Participant 2 answered this question as follows "I believe it will increase success when it is used in the right way". When asked about the advantages of tablet computers he answered the question by saying, "Materials such as tablets should be used in the technology age. If children are curious about the technology we can also obtain information that way and they will learn in a more enjoyable manner". Participants stated that they did not use tablet computers although they believed tablets would have the benefits that were specified and this was because the benefits in question did not have any chance to be reflected since tablet computers were used for playing games out of their purpose.

When teachers were asked about why they did not use the tablet computers or why they answered the relevant question "I cannot use them" as expressed by Participant 4, they stated that they were positive and wiling about using tablet computers at first and they made a clear confession and said that only general knowledge was given to them about the subject and they were educated about what the tablet computers were and for what they were used during in-service training and they were not taught about many subjects such as how these tablets could be used, how they could be integrated into educational process, how tablets could be used and managed inside the classroom, how the updates or other procedures could be done, how the tablets could be enriched, how the tablets could be integrated to smart boards and how the connection between teacher's tablet and a student's tablet could be established and how they could be managed. Inefficiency in in-service training activities was the main justification for the teacher who did not use, or in other words could not use the tablets.

All participants who believed that tablets not used for their intended purposes would decrease the rate of success stated that efficiency could be achieved if the tablets were used according to the purposes specified and explained at the beginning, technical problems were solved and most importantly control mechanisms were developed. They stated that the Ministry of Education only distributed the tablets and no teacher knows completely what to do with the tablets and how s/he can integrate tablets with the educational processes.

Table 2. Quantification of qualitative data regarding the first theme

\begin{tabular}{|cl|c|c|}
\hline \multicolumn{1}{|c|}{ Situation } & $\mathrm{n}$ & $\%$ \\
\hline 1. & Not using tablet computers & 6 & 100 \\
\hline 2. & Positive attitude towards tablet computers & 6 & 100 \\
\hline 3. & $\begin{array}{l}\text { Attitude believing tablet computers will } \\
\text { increase the rate of success in education }\end{array}$ & 4 & 66.7 \\
\hline 4. & $\begin{array}{l}\text { Believing in the advantages of tablet } \\
\text { computers }\end{array}$ & 4 & 66.7 \\
\hline 5. & $\begin{array}{l}\text { Thinking that students use tablets for } \\
\text { playing games }\end{array}$ & 6 & 100 \\
\hline 6. & $\begin{array}{l}\text { People having problems with tablet } \\
\text { computers }\end{array}$ & 6 & 100 \\
\hline
\end{tabular}

\section{2) Technical Problems Encountered with Tablet Computers and Solution Suggestions}

Participants stated that tablet computers were not used according to their intended uses and they were used by students only for games. Participants stated technical problems as another reason why tablet computers used for purposes other than the intended uses in FATIH Project affected success rate and efficiency adversely. When asked 
about what these technical problems were, they gave the following answers:

1. Software and tablets special for teachers are not presented to them.

2. Tablets do not have enriched materials, Z-books, visual materials, content about how they will manage teaching and existing content's not being updated regularly,

3. Having no prepared activities

4. Tablets breaking down in a short time

5. EBA portal contributing to the updates being insufficient in terms of content although it has a quality design

6. Having charge problems

7. Having no internet connection for schools

8. Having no integration between the tablet and the smart board

9. Not being able to remote control smart boards and students' tablets

10. Not being able to open file formats like PDF/DOC/AVI etc. with the tablets

11. Having slow processors and not being able to run some programs

12. Having problems in the releases of the automatic updates

13. Installed programs being removed when the computers are turned off.

When these problems were analyzed one by one, it was determined that the most important technical problem among them was teachers' not being able to control the tablets and it was stated by the participants that this problem should be solved urgently. Participant 2 expressed the control problem with the answer "We are having problems controlling the students. Tablets are not under our control. It is like when children are reading comic books between books". Also participants stated that in the cases when the tablets are not controlled by teachers students would not use the tablets for their intended purposes, they would not see tablets as educational tools just like they currently do, they would keep using tablets for games and visit illegal web sites by breaking their passwords. Stating that the control problems have two dimensions, the participants said that a quality and comprehensive training should be given to them about how the control should be ensured and they also suggested software or hardware allowing control on tablets to be integrated with the tablet computers. They said that with the development of remote control systems teachers could act like a guide for the students and show them how they could use the tablets for intended purposes.

Another problem that is encountered is that the tablets cannot go further because of their insufficient hardware, they do not have enriched materials, z-books and audio-visual materials intended for gains and activities regarding each lesson. Another problem is that there are no other developed portals other than EBA for enriching the content. Teachers believe that, even if it will be only at a small degree, problems encountered will be solved if the activities prepared in the tablets can be presented.

Having no integration between smart boards and tablets in particular in the FATIH project, which has more than one component such as tablets, smart board, interactive board and internet, was perceived as another reason why it is not used inside the classrooms. They also stated that the tablet computers are incompatible with Microsoft office programs and animation programs.

Most of the participants stated that tablets distributed to the students broke down in a short time and they were very far from covering the needs of the age in terms of both software and hardware. Participants stated that schools did not have internet connection, which makes a great contribution for the tablets to reach their goals, and they could not use media tools. Participant 5 expressed the problems he had with tablet computers by saying: "Installed programs are removed automatically. I install a program and turn off the tablet and I cannot find the program when I turn it on again. Tablets are resetting themselves. I cannot install the programs I want on the tablets. School's not having internet connection also affects this."

Table 3. Quantification of the qualitative data regarding the second subject

\begin{tabular}{|ll|c|c|}
\hline \multicolumn{1}{|c|}{ Situation } & $\mathrm{n}$ & $\%$ \\
\hline 1. & $\begin{array}{l}\text { Participation in in-service training with tablet } \\
\text { computers }\end{array}$ & 5 & 84 \\
\hline 2. & $\begin{array}{l}\text { Thoughts suggesting the in-service training } \\
\text { that is given is insufficient. }\end{array}$ & 6 & 100 \\
\hline 3. & $\begin{array}{l}\text { Opinions suggesting in-service training } \\
\text { activities are insufficient }\end{array}$ & 6 & 100 \\
\hline 4. & $\begin{array}{l}\text { In-service training activities should be redone } \\
\text { with practices }\end{array}$ & 6 & 100 \\
\hline 5. & Having technical problems regarding tablets & 6 & 100 \\
\hline 6. & Thoughts about having control problem & 6 & 100 \\
\hline 7. & $\begin{array}{l}\text { Thoughts about solving the problems } \\
\text { regarding lack of infrastructure }\end{array}$ & 6 & 100 \\
\hline 8. & $\begin{array}{l}\text { Opinion suggesting tablet computers and } \\
\text { training portals have insufficient content }\end{array}$ & 6 & 100 \\
\hline 9. & $\begin{array}{l}\text { Thoughts suggesting there should be an } \\
\text { internet connection }\end{array}$ & 6 & 100 \\
\hline
\end{tabular}

\section{Conclusion and Discussion}

Tablets were started to be used in educational process after their distribution in schools starting from 2010 within the scope of FATIH Project in Turkey. Teachers' opinions regarding table computers were investigated in detail within the scope of the study and it was determined that they had positive attitudes regarding the use of tablet computers. Attitudes of teachers constitute an important factor for FATIH Project to succeed. All the participants thought that using tablet computers in education would increase rate of success, render learning enjoyable and save time. In the studies conducted by Kamacı and Durukan [32] and Özkale and Koç, [42], it was concluded that teachers had positive attitudes regarding tablet computers. 
It was concluded from the study that the participants did not use tablet computers when teaching lessons although they had positive attitudes towards tablet computers. It was determined as a result of the interviews conducted that the main reason why participants did not use tablet computers was technical problems. Having no internet connection, tablets' breaking down in a very short time, not being able to install any programs, having no interaction with the smart board, having no z-books on them and having insufficient content are among the technical problems. Studies conducted by Aktaş et al.[4], Çetinkaya and Keser [17], Ekici and Y1lmaz [21], Gürol, Donmuş and Arslan [29], Karataş and Sözcü [35], Kurt et al. [38] ; Pamuk et al. [44] revealed that teachers had problems using tablet computers. It is necessary for the content of the tablets to be enriched, animations and videos appropriate for each lesson to be loaded into tablet computers, hardware problems to be solved and current infrastructure to be rearranged.

The other problem in the implementation of FATIH Project is the problem about control. All participants stated that they could not control the tablets of their students, students did not use tablets as educational tools, they played games with the tablets in their hands, which causes a management problem. Study conducted by Ayvacı, Bakırcı and Başak [6], Aktaş et al., [4] supports this finding. Management problem is one of the reasons why participants did not prefer tablet computers. It is necessary to solve the problem of controlling tablet computers within the classroom by using various software and programs [44].

Based on the interviews made with participants in the scope of the study, it was concluded that in-service training given in FATIH project was insufficient. Participants stated that general information regarding the project was given during in-service training and detailed information was not given about how the tablet computers could be used. Similar studies in the literature revealed problems encountered in in-service education. In-service trainings did not yield intended efficiency as they could not cover the needs since they were given in a very general format and technical knowledge and skills were focused on during this training, they did not include branch-specific in-service training and teachers did not make any practices during in-service trainings [3, 6, 44, 50]. Banoğlu [8] and Altan [5], on the other hand, state in their studies that it is difficult to achieve efficiency from in-service trainings given within the scope of FATIH Project if they do not improve their self-sufficiency and develop positive attitudes for technology. Technological knowledge of the teachers is an important factor for FATIH Project to succeed. In-service trainings are important for teachers to develop their technological knowledge and skills. Within this context, it is suggested for in-service trainings to be given face to face or online specifically for every branch and to be constantly provided and be application-oriented [36].

It is necessary to rearrange current infrastructure, to give applied in-service training to teachers and to create awareness among students in terms of tablet computer usage for the FATIH project to succeed. Improvement of the content of tablet computers and solving technical problems are also important in terms of having positive results from the project.

Turkish government has invested millions of dollars for FATIH project which it has carried into effect to keep up with the requirements of modern age and to integrate technology in education. Unfortunately, tablets have become play thing for students, and are discarded and not used by teachers. This indicates that there are significant obstacles for FATIH project to realize its objectives. The project, which was initially defined as a revolution, is now gradually turning into a disappointment. It is suggested that decision makers develop additional action plan for the solution of the problems that have negative effects on the success of the project and that have been defined throughout the study.

\section{REFERENCES}

[1] Adıgüzel, T., Gürbulak, N., Sarıçayır, H. (2011). Akıllı Tahtalar ve Ögretim Uygulamaları. Mustafa Kemal Üniversitesi Sosyal Bilimler Enstitüsü Dergisi, 8(15), 457 471.

[2] Akgün, E., Yılmaz, O. E., Seferoğlu, S. S. (2011). Vizyon 2023 Strateji Belgesi ve Frrsatları Artırma ve Teknolojiyi İyileştirme Hareketi (FATIH) Projesi: Karşılaştırmalı Bir İnceleme, Akademik Bilişim 2011, MALATYA: İnönü Üniversitesi.

[3] Akıncı, A., Kurtoğlu, M., Seferoğlu, S. S. (2012). Bir Teknoloji Politikası Olarak FATIH Projesinin Başarılı Olması İçin Yapılması Gerekenler: Bir Durum Analizi Çalışması, Akademik Bilişim 2012, UŞAK: Uşak Üniversitesi.

[4] Aktaş, İ., Gökoğlu, S., Turgut, E. Y., Karal, H. (2014). Öğretmenlerin FATIH Projesine Yönelik Görüşleri: Farkındalık, Öngörü ve Beklentiler. Necatibey Eğitim Fakültesi Elektronik Fen ve Matematik Ĕ̆itimi Dergisi, 8 (1), 257- 286.

[5] Altan, T. Ve Tüzün, H. (2011).Teknoloji- Zengin Bireysel Öğrenme Ortamlarının FATIH Projesindeki Yeri, Akademik Bilişim 2011, MALATYA: İnönü Üniversitesi.

[6] Ayvacı, H. Ş., Bakırcı, H. ve Başak, M.H. (2014). FATIH Projesinin Uygulama Sürecinde Ortaya Çıkan Sorunların İdareciler, Ögretmenler ve Öğrenciler Tarafindan Değerlendirilmesi. Yüzüncü Yıl Üniversitesi Ĕ̆itim Fakültesi Dergisi, 11(1), 20-46.

[7] Bağcı, H. (2013). FATIH Projesi Çerçevesinde Ortaöğretim Öğrencilerinin Etkileşimli Tahtaya Yönelik Görüşlerinin İncelenmesi, OKAN ÜNIVERSİTESI, Sosyal Bilimler Enstitüsü, İstanbul.

[8] Banoğlu, K., Madenoğlu, C., Șengül, U. ve Dede A. (2014). FATIH Projesine Yönelik Öğretmen Görüşlerinin İncelenmesi (Eskişehir İli Örneği). Eğitim Bilimleri Araştırmaları Dergisi, 4(1), 39 -58.

[9] Balc1, S. (2013). Türkçe Dersinde Tablet PC Pilot 
Uygulamasıyla Öğretim Gören Öğrencilerin Tutumlarını Belirlemeye Yönelik Ölçek Çalışması. Turkish StudiesInternational Periodical for The Languages, Literature and History of Turkish or Turkic, 8(1), 855-870.

[10] Bonds, M.J.,Raacke \& Raacke, J.D. (2008). Using Tablet Pcs in the Classroom: An Investigation of Students' Expectations and Reactions. Journal of Instructional Psychology, $35(3), .235-239$.

[11] Bush, M.H. \& Cameron, A. H. (2011). Digital Course Materials: A Case Study Of The Apple Ipad in The Academic Environment, PEPPERDINE UNIVERSITY, Graduate School of Education and Psychology, Malibu.

[12] Byno, K.J. (2014). Integratıng iPad Technology into the Classroom: A Study Investigating The Experiences Educators Encounter, LAMAR UNICERCITY, The Faculty of the College of Graduate Studies, Beaumont.

[13] Creswell, J. W. (2013). Araştırma deseni (Çev Edt: Demir, S. B.). Ankara: Eğiten Kitap.

[14] Creswell, J. W. (2014). Nitel araştırma yöntemleri (Çev Edt: Bütün, M. ve Demir, S. B). Ankara: Siyasal Kitap.

[15] Crichton, S., Pegler, K. \& White, D. (2012). Personal Devices in Public Settings: Lessons Learned From an iPod Touch/ iPad Project. Electronic Journal of e-Learning, 10(1), 23-31.

[16] Çağlar, E. (2012). Yeni Medya Dolayımlı Eğitim Ortamında FATIH Projesi Öğretmenlerinin Pedagojik Uygulamaların Uluslararası Öğretmen Standartları İle Karşılaştırılması, KADİR HAS ÜNNIVERSITESİ, Sosyal Bilimler Enstitüsü, İstanbul.

[17] Çetinkaya, L. ve Keser, H. (2014). Öğretmen ve Öğrencilerin Tablet Bilgisayar Kullanımında Yaşadıkları Sorunlar ve Çözüm Önerileri. Anadolu Journal of Educational Sciences International, 4(1), 13 - 35 .

[18] Çiftçi, S., Taşkaya, S. M. ve Alemdar, M. (2013). Sınıf Öğretmenlerinin FATIH Projesine İlişkin Görüşleri. Elementary Education Online, 12(1), 227-240.

[19] Demirer, V., Saban, A., Küçük, Ş., Şahin, İ. (2011). Bilim Teknolojileri Öğretmen Adaylarının FATIH Projesi Hakkındaki Görüşlerinin Değerlendirilmesi, 11. Uluslar arası Teknoloji Konferansı, Mayıs, İstanbul.

[20] Dündar, H. Ve Akçayır M. (2014). Implementing tablet PCs in schools: Students' attitudes and opinions. Computers in Human Behavior, 32, 40-46.

[21] Ekici, S. ve Y1lmaz, B. (2013). FATIH Projesi Üzerine Bir Değerlendirme. Türk Kütüphaneciliği, 27(2), 317- 339.

[22] Enriquez, A. G. (2007). Developing an interactive learning network using tablet pcs in sophomore level engineering courses. American Society of Engineering Education Conference and Exposition, 24-27.

[23] Ertmer, P. A. (2005). Teacher pedagogical beliefs: The final frontier in our quest for technology integration?. Educational Technology Research and Development, 53(4), 25-39.

[24] Eryılmaz, S. ve Salman Ş. (2014). FATIH Projesi Kapsamında Yer Alan Öğretmen ve Öğrencilerin Projeden Beklentileri ve Bilişim Teknolojileri Kullanımına Karşı Algıları. Elektronik Mesleki Gelişim ve Araştırma Dergisi, 2(1), $46-63$.
[25] http://FATIHprojesi.meb.gov.tr/tr/icerikincele.php?id=6 (Erişim Tarihi: 27.10.2014).

[26] Galligan, L., Loch B., McDonald, C. \& Taylor, J. A. (2010). The use of tablet and related technologies in mathematics teaching, Australian Senior Mathematics Journal, 24(1), $38-51$.

[27] Genç, M. Ve Genç T. (2013). Öğretmenlerin Mesleki Gelişmeleri Takip Etme Durumları: FATIH Projesi Örneği. Ahi Evran Üniversitesi Kırşehir Ë̆itim Fakültesi Dergisi, 14(2), 61-78

[28] Güllüpınar, F., Kuzu, A., Dursun, Ö.Ö., Kurt, A.A. ve Gültekin, M. (2013). Milli Eğitimde Teknoloji Kullanımı ve Sonuçları: Velilerin Bakış Açısından FATIH Projesi'nin Pilot Uygulamasının Değerlendirilmesi. SDÜ Fen Edebiyat Fakültesi Sosyal Bilimler Dergisi, 30, 195-216.

[29] Gürol, M., Donmus, V. ve Arslan, M. (2012). İlköğretim Kademesinde Görev Yapan Sınıf Öğretmenlerinin FATIH Projesi İle İlgili Görüşleri. Eğitim Teknolojileri Araştırmaları Dergisi, 3(3).

[30] Jhonson, M.G. (2013). Using Tablet Computers With Elementary School Students With Special Needs: The Practices and Perceptions of Special Education Teachers and Teacher Assistants. Canadian Journal of Learning and Technology, 39(4), 1-12.

[31] Johnson, B. \& Chrıstensen, L. (2014), Eğitim Araştırmaları (Çev Edt: Demir, S. B.), Ankara: Eğiten Kitap.

[32] Kamac1, E. ve Durukan E. (2012). Araştırma Görevlilerin Eğitimde Tablet Bilgisayar Kullanımına İlişkin Görüşleri Üzerine Nitel Bir Araştırma(Trabzon Örneği). Uluslararası Türkçe Edebiyat Kültür Eğitim Dergisi, 1(3), 203-215.

[33] Kalelioğlu, F. ve Akbaba-Altun, S. (2014). Middle School Students' Perceptions and Expectations About Tablet PCs In Turkey. International Journal of Multidisciplinary Thought, 4(2), 301-307.

[34] Karal, H., Aktaş, İ., Turgut, Y.E., Gökoğlu, S., Aksoy N. Ve Çakır, Ö. (2013). FATIH Projesine Yönelik Görüşleri Değerlendirme Ölçeği: Güvenirlik ve Geçerlilik Çalışması. Ahi Evran Üniversitesi, Kırşehir Ĕ̆itim Fakültesi Dergisi, 14(2), 325-348.

[35] Karataş, H. İ. Ve Sözcü, F. Ö. (2013). Okul Yöneticilerinin FATIH Projesine İlişkin Farkındalıkları, Tutumları ve Beklentileri: Bir Durum Analizi, Elektronik Sosyal Bilimler Dergisi, 12(47), 41-62.

[36] Kayaduman, H., Sarıkaya, M. ve Seferoğlu, S.S. (2011). Eğitimde FATIH Projesinin Öğretmenlerin Yeterlik Durumları Açısından İncelenmesi, Akademik Bilişim 2011, MALATYA: İnönü Üniversitesi.

[37] Kaymak, İ., ve Yılmaz, M. (2012) Eğitim Teknolojileri Seçimi Örnekleri.

[38] Kurt, A.A., Kuzu, A., Dursun, Ö. Ö., Güllüpınar, F. ve Gültekin, M. (2013). FATIH Projesinin Pilot Uygulama Sürecinin Değerlendirilmesi: Öğretmen Görüşleri. Journal of Instructional Technologies \& Teacher Education, 1(2), 1 -23.

[39] Lim, K. Y. (2011). What does the Tablet PC mean to you? A phenomenological research. Innovations in Education and Teaching International, 48(3), 323-333. 
[40] Marshall, C., \& Rossman, G. B. (2011). Designing qualitative research. Thousand Oaks, CA: Sage.

[41] Miles, M. B., \& Huberman, A. M. (1994). Qualitative data analysis (2nd edition). Thousand Oaks, CA: Sage.

[42] Özkale, A., Koç, M. (2014). Tablet Bilgisayarlar ve Eğitim Ortamlarında Kullanılması: Bir Alanyazın Taraması. SDU International Journal of Educational Studies, 1(1), 24-35.

[43] Patton, Q. M. (2014) Nitel araştırma ve değerlendirme yöntemleri (Çev Edt: Bütün, M. ve Demir, S. B). Ankara: Pegem A.

[44] Pamuk, S., Çakır, R., Ergun, M., Yılmaz, H.B., Ayas, C. (2012) Öğretmen ve Öğrenci Bakış Açısıyla Tablet Pc ve Etkileşimli Tahta Kullanımı: FATIH Projesi Değerlendirmesi. Kuram ve Uygulamada Eğitim Bilimleri, 13(3), 1799 -1822.

[45] Saine, P. (2012). IPads, and the SMARTBoard: Transforming literacy instruction and student learning. New England Reading Association Journal, 47(2), 74-79

[46] Sayır, M. F (2014). FATIH Projesi Kapsamında Kullanılan Akıllı Tahtalara Karşı Öğretmen ve Öğrenci Tutumları ve
Akıllı Tahtaların Konuşma Becerisi Üzerindeki Etkileri, ÇAĞ ÜNIVERSITTESİ, Sosyal Bilimler Enstitüsü, Mersin.

[47] Swonson, L. C. (2012). Impact of iPads on Reading Fluency in a Sixth-Grade Reading Classroom, SOUTHWEST MINNESOTA STATE UNIVERSITY, Education Department, Marshall.

[48] Tekerek, M., Altan, T., Gündüz, İ. (2014). FATIH Projesinde Tablet PC Kullanımına Yönelik Öğrenci Tutumlarının İncelenmesi. Bilişim Teknolojileri Dergisi, 7(2), 21 -27.

[49] Vallance, M., \& Numata, H. (2011). Beyond potential: A two-year study of iPod use in a Japanese university. International Journal of Learning Technology, 6(4), 324-340

[50] Yoon, C. \& Sneddon, J. (2011). Student Perceptions of Effective Use of Tablet PC Recorded Lectures in Undergraduate Mathematics Courses. International Journal of Mathematical Education in Science and Technology, 42(4), 424-445.

[51] Yıldırım, A. ve Şimşek, H. (2013). Nitel Araştırma Yöntemleri. Ankara: Seçkin. 